\title{
УДК 343.625.3
}

DOI https://doi.org/10.32840/1813-338X-2021.2.16

\section{О. Я. Переверза}

кандидат юридичних наук, старший викладач кафедри права

Придунайської фрілії Міжрегіональної Академії управління персоналом

М. К. Кулава старший викладач кафедри права

Придунайської фрілії Міжрегіональної Академії управління персоналом

\section{Н. А. Філіпова}

в. о. завідувача кафедри права

Придунайської філії

Міжрегіональної Академії управління персоналом

\section{ПРОБЛЕМНІ ПИТАННЯ КРИМІНАЛЬНО-ПРАВОВОЇ, КРИМІНОЛОГІЧНОЇ ХАРАКТЕРИСТИКИ ТА РОЗСЛІДУВАННЯ КРИМІНАЛЬНИХ ПРОСТУПКІВ 3 УХИЛЕННЯ ВІД СПЛАТИ АЛІМЕНТІВ НА УТРИМАННЯ ДІТЕЙ}

3 огляду на зміни, які відбулися у сімейному, кримінальному, кримінально-процесуальному законодавстві, та зростання кількості дітей, які потребують правового захисту від несплати однім із батьків аліментів на їх утримання, актуальним є комплексне вирішення проблеми засобами різних галузей права.

Дослідження проведене з урахуванням нововведень до ст. 12 КК України та глави 25 КПК України відносно поняття «кримінальний проступок» та процесуальної регламентації особливостей досудового розслідування кримінальних проступків.

Проведено кримінально-правову, кримінологічну та криміналістичну характеристику вчинення кримінального проступку, передбаченого cm.164 КК України. Аналіз здійснено на підставі статистичних даних ЄРДР та Єдиного реєстру судових рішень за період з 01.07.2020 р. по 31.12.2020 p.

Була здійснена спроба визначити інші основні елементи методики розслідування кримінальних проступків иієї категорії (обставини, які потрібно встановити по даній категорії справ, особливості початкового етапу розслідування, здійснення первинних слідчих дій, особливості подальшого етапу розслідування), тобто йдеться про зародження фрормування нової методики розслідування досліджуваного кримінального проступку.

Сформовано перелік обставин, які потрібно встановити по даній категорії справ на підставі аналізу ст. 91 КПК та складу ст. 164 КК: чи мало місце ухилення від сплати коштів (за який саме період, де це відбулося); розмір грошових коштів, які потрібно було сплатити; за який саме спосіб вчинення діяння; хто має сплатити кошти; якими саме доказами підтверджується винуватість особи.

Констатовано, що ускладнює початковий етап дізнання по цій категорії справ той фракт, що зәідно з ч. $1 \mathrm{~cm} .477$ КПК ухилення без обтяжуючих обставин (ч. $1 \mathrm{~cm} .164 \mathrm{KK}$ ) належить до категорії справ приватного обвинувачення, тобто дізнавач може розпочати провадження тільки після отримання заяви потерпілого. Підняте питання про тактичні аспекти моменту повідомлення про підозру в ракурсі трактування строків дізнання по процесуальному законодавству.

Робиться висновок, що практичні працівники мають значні труднощі в процесі розслідування кримінальних проступків зазначеної категорії з огляду на те, що згідно 
з процесуальним законодавством дізнанням по цій категорії справ можуть займатися нарівні з підрозділом дізнання, інші уповноважені особи Національної поліції, що потребує подальшого удосконалення процесуальних та методичних аспектів досліджуваної проблеми.

Ключові слова: кримінально-правова характеристика, криміналістична характеристика, кримінологічна характеристика, дізнання, ухилення, сплата аліментів, кримінальний проступок, методика розслідування.

Постановка проблеми. Проблеми предмету позову, кримінально-правової характеристики та процесу розслідування кримінальних правопорушень, передбачених ст. 164 Кримінального кодексу України (далі - КК), неодноразово висвітлювались у науковій літературі, при цьому аналіз був присвячений кожній із проблем окремо.

Актуальність дослідження зумовлена тим, що 22 листопада 2018 року Верховною Радою України було прийнято зміни до ст. 12 КК України (введено поняття - кримінальний проступок [1]) та глави 25 КПК [2] (змінено процесуальну регламентацію особливостей досудового розслідування кримінальних проступків).

Згідно з новими вимогами, з липня 2020 року ст. 164 КК України на підставі аналізу ч. 2 ст. 12 КК належить до кримінальних проступків.

Маємо зазначити, що стаття 51 Конституції України наголошує, що сім'я, дитинство, материнство й батьківство охороняються державою та батьки зобов'язані утримувати дітей до їх повноліття [3]. На врахуванні інтересів дітей наголошує також Конвенція $\mathrm{OOH}$ про права дитини від 20.11.1989 року [4], ст.ст. 180-181 Сімейного кодексу України [5], судова практика у справах про злісне ухилення від сплати аліментів на утримання дітей [6], практичні працівники - адвокати, які захищаються цю вразливу категорію населення [7], адвокати Вищої школи адвокатури НААУ, адвокати [8].

Аналіз останніх досліджень і публікацій. В теорії сімейного, кримінального, цивільно-процесуального, кримінального процесуального права та у криміналістичній літературі окремим проблемам ухилення від сплати аліментів на утримання дітей приділялась увагу такі науковці, як А. Бабенко, Д. Євтєєва, О. Кухаренко, А. Оксаніченко, І. Семеногов, А. Столітній. Але проведене науковцями дослідження потребує доповнення у зв'язку із змінами законодавства та комплексністю проблеми, яка не обмежується однією галуззю права.

З 01.07.2020 року у практичних працівників повинні бути конкретні рекомендації по застосуванню цих змін.
Метою статті $\epsilon$ висвітлення деяких дискусійних проблем, які залишаються поза увагою вчених, а саме:

- комплексна кримінально-правова характеристика досліджуваного кримінального правопорушення;

- окремі аспекти криміналістичних, кримінологічних та кримінально-процесуальних проблем, які виникають під час розслідування досліджуваного кримінального правопорушення (фактично йдеться про зародження формування нової методики розслідування кримінального проступку).

Виклад основного матеріалу. Досліджуючи обрану тему, маємо підкреслити, що методиці досудового розслідування ухилення від сплати аліментів на утримання дітей приділяли увагу фрагментарно тільки деякі науковці. Так, в 2015 році А.В. Столітній [9, с. 178] піднімає проблему специфіки початку досудового розслідування цього злочину (на час дослідження) на підставі повідомлень державної виконавчої служби.

За період з 01.07.2020-31.12.2020 року на підставі аналізу Єдиного державного реєстру судових рішень було ухвалено 382 вироки [10] за ст. 164 КК України (для порівняння з 01.01.2020-31.12.2020 - 618 вироків), а по Одеській області таких рішень за півроку було усього вісім [11], це фрактично підкреслює неефективність досудового розслідування цих проступків та недостатню караність цієї статті КК.

В такому великому місті, як Одеса, з 01.07.2020 по 31.12.2020 року було винесено всього один вирок за цією статтею, який вступив в законну силу. Ці статистичні данні свідчать, що практичні працівники мають значні труднощі в процесі розслідування кримінальних проступків цієї категорії. Про наявність проблеми свідчать і дані аналізу Єдиного реєстру боржників (підкатегорія «ухилення від сплати аліментів»), в якому станом на 16.01.2021 року міститься 175175 записів [12]. При цьому потрібно враховувати, що до Реєстру вносяться тільки фізичні особи, які мають заборгованість по аліментам більше ніж 3 місяці (тобто йдеться про термін, що прописаний в якості критерію 
«злісності» у примітці до ст. 164 КК) і відносно яких відкрите виконавче провадження.

На наявність проблеми вказує також аналіз статистичних даних, що містяться на сайті Офрісу Генерального прокурора за 2020 рік про зареєстровані кримінальні правопорушення та результати іх досудового розслідування.

Аналіз (див. таблиця 1) проведено на підставі співвідношення даних про повідомлення про підозру по ст.164 КК в період з 01.01.2020 - 30.06.2020 (далі - попередній період) та з 01.01.2020 - 31.12.2020 року, співставлення даних дозволяє виокремити інформацію про кількість винесених повідомлень про підозру в скоєнні кримінального проступку -ухилення від сплати аліментів на утримання дітей та подальші результати розслідування по них.

Якісний склад осіб, які скоїли ці правопорушення, проведено на підставі аналізу статистичних даних, розташованих на сайті Офрісу Генерального прокурора за 2020 рік (див. таблиця 2), щодо кількості осіб, які вчинили кримінальні правопорушення за цією статтею.

На підставі аналізу представлених даних можна скласти первинну характеристику вчинення досліджуваних нами проступків, на відміну від раніше облікованого злочину.

Дізнання по цим проступкам фрактично здійснювали підрозділи Національної поліції, та в цілому за півроку усього обліковано 1031 кримінальних правопорушень цієї категорії, що на 43 кримінальних правопорушення менше, ніж у попередній період. Повідомлення про підозру вручено 470 особам, що на 107 осіб більше, ніж у попередній період.

3 обвинувальним актом до суду направлено 463 кримінальних провадження, що на 110 більше, ніж у попередньому періоді. На жаль, по цій категорії справ 1906 проваджень закрито, що на 723 провадження більше у порівнянні з попереднім періодом.

Як свідчить статистика, фактично всі вони закриті за п.п. 1, 2, 4, 6, 9-1 ч. 1 ст. 284 КПК України, тобто ці підстави не пов'язані з недоказаністю вини у скоєнні кримінального правопорушення, а пов'язані з подією правопорушення (це відсутність або події, або складу кримінального правопорушення; існує вирок по тому самому обвинуваченню, що набрав законної сили, або постановлена ухвала суду про закриття кримінального провадження по тому самому обвинуваченню; існує нескасована постанова слідчого, дізнавача, прокурора про закриття кримінального провадження по п. 1, 2, 3, 9 ч. 1 ст. 284 КПК, у кримінальному провадженні щодо самого того діяння).

У звітному періоді по 564 провадженням не прийнято рішення (про зупинення або закінчення) дізнання, що на 154 провадження менше, ніж у попередній період.

Можемо підсумувати, що у період з 01.07.2020 р. по 31.12.2020 року обліковано менше кримінальних правопорушень, але збільшилась кількість осіб, яким повідомлено про підозру, та кількість проваджень, що надіслані до суду з обинувальним актом. В той же час збільшилось кількість закритих проваджень, що фактично свідчіть про неспроможність органів дізнання доказати вину особи у скоєнні досліджуваного нами проступку та повідомити про підозру. Водночас прискорена процедура розслідування кримінальних проступків сприяє зменшенню відсотка проваджень, по яких не прийняте рішення на кінець звітного періоду.

Наведені статистичні дані дають змогу виокремити криміналістичну характеристику особи, яка вчинила цей проступок. Так, у більшості випадків це особи, які не ухиляються від органів дізнання. Цей висновок можна зробити на підставі того, що тільки відносно двох осіб досудове слідство було зупинено за ст. 280 КПК у зв'язку із тим, що не було встановлено місце знаходження підозрюваного.

В більшості випадків це особи, які раніше не вчиняли кримінальні правопорушення (у 463 справах, які 3 обвинувальним актом були спрямовані до суду осіб, які раніше вчиняли кримінальні правопорушення було всього 62), у порівнянні з попереднім періодом таких осіб стало менше на 27, незважаючи на те, що збільшилась кількість проваджень, які спрямовано до суду з обвинуальним актом.

Характеризуючи віковій склад осіб, які скоюють кримінальний проступок, передбачений ст. 164 КК, можна зазначити, що більшість осіб віком від 29-39 років (276 осіб) та віком від 40-54 років (126 осіб), при цьому у порівнянні з попереднім півріччям спостерігаємо зростання кількості осіб відповідно на 64 і 28 осіб у кожній віковій категорії. Питома вага жінок 13 осіб (на 11 осіб менше, ніж у попередньому періоді), що свідчить про те, що правопорушниками в більшості випадків є чоловіки.

За освітнім рівнем особа, яка ухиляється від сплати аліментів, переважно має повну загальну середню або базову загальну середню освіту (318 осіб) та професійно-технічну освіту (100 осіб), кількість осіб з повною вищою або 


\section{Загальні відомості про кількість зареєстрованих кримінальних правопорушень по ст. 164 КК та результати їх досудового розслідування}

\begin{tabular}{|c|c|c|c|c|}
\hline $\begin{array}{l}\text { Показник по ст. } 164 \text { КК України (в тому числі, } \\
\text { які перебувають у провадженні Національної поліції). } \\
\text { Підготовлено на підставі аналізу: } \\
\text { - розділу } 1 \text { ( таб.1.6;таб.2.4), розділу } 9 \text { звітів } \\
\text { за січень-грудень } 2020 \text { року; } \\
\text {-розділу } 1 \text { (таб.1.6) розділ 4(таб.4.4.), розділ } 10 \text { звіту } \\
\text { за січень-червень } 2020 \text { року [13]. }\end{array}$ & 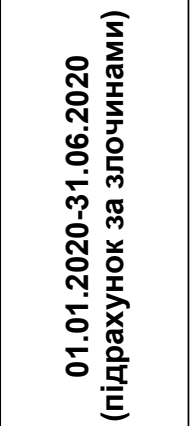 & 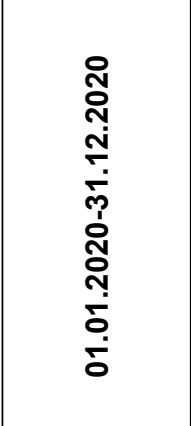 & 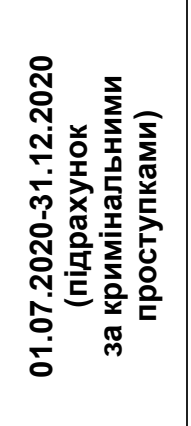 & 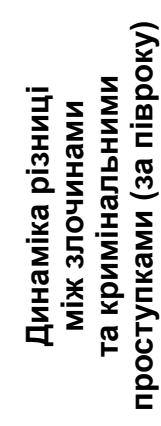 \\
\hline $\begin{array}{l}\text { Розділ } 1 \\
\text { Обліковано кримінальних правопорушень у звітному періоді }\end{array}$ & $1074(1073)$ & $2105(2103)$ & $1031(1030)$ & $-43(42)$ \\
\hline $\begin{array}{l}\text { Кримінальні правопорушення, у яких особам вручено } \\
\text { повідомлення про підозру }\end{array}$ & $363((363)$ & $833(833)$ & $470(470)$ & $\begin{array}{l}+107 \\
(+107)\end{array}$ \\
\hline \multicolumn{5}{|l|}{$\begin{array}{l}\text { Кримінальні правопорушення у провадженнях, досудове } \\
\text { розслідування у яких зупинено відповідно до ст. } 280 \text { КПК, } \\
\text { у том числі: }\end{array}$} \\
\hline у зв'язку з захворюванням підозрюваного; & 0 & 0 & 0 & 0 \\
\hline коли місцезнаходження підозрюваного невідомо; & 0 & $2(2)$ & $2(2)$ & +2 \\
\hline $\begin{array}{l}\text { Коли слідчий суддя відмовив у задоволенні клопотання про } \\
\text { здійснення спеціального досудового розслідування }\end{array}$ & 0 & 0 & 0 & 0 \\
\hline $\begin{array}{l}\text { у зв'язку з виконанням процесуальних дій у межах } \\
\text { міжнародного співробітництва }\end{array}$ & 0 & 0 & 0 & 0 \\
\hline \multicolumn{5}{|l|}{$\begin{array}{l}\text { Кримінальні правопорушення, за якими провадження } \\
\text { направлені до суду (п.п. 2,3 ст. } 283 \text { КПК): }\end{array}$} \\
\hline з обвинувальним актом; & $353(353)$ & $818(818)$ & 463(463) & +110 \\
\hline $\begin{array}{l}\text { з клопотанням про звільнення від кримінальної } \\
\text { відповідальності; }\end{array}$ & 0 & 0 & 0 & 0 \\
\hline $\begin{array}{l}\text { з клопотанням про застосування примусових заходів } \\
\text { медичного характеру; }\end{array}$ & 0 & 0 & 0 & 0 \\
\hline $\begin{array}{l}\text { з клопотанням про застосування примусових заходів } \\
\text { виховного характеру; }\end{array}$ & 0 & 0 & 0 & 0 \\
\hline $\begin{array}{l}\text { Кримінальні правопорушення, за якими провадження } \\
\text { скеровані до суду з клопотанням про закриття за п. 3-1 ч. } 1 \\
\text { ст. } 284 \text { КПК }\end{array}$ & 0 & 0 & 0 & 0 \\
\hline \multicolumn{5}{|l|}{$\begin{array}{l}\text { Кримінальні правопорушення, вчинені окремими категоріями } \\
\text { осіб, провадження за якими закінчені: }\end{array}$} \\
\hline особами, які раніше вчиняли кримінальні правопорушення; & $89(89)$ & 151(151) & $62(62)$ & $-27(-27)$ \\
\hline групою осіб; & $1(1)$ & $2(2)$ & 1(1) & 0 \\
\hline \multicolumn{5}{|l|}{ особами у стані алкогольного сп'яніння; } \\
\hline \multicolumn{5}{|l|}{ неповнолітніми або за їх участю. } \\
\hline $\begin{array}{l}\text { Кримінальні правопорушення, у яких провадження закрито, } \\
\text { В тому числі усього: }\end{array}$ & $1183(1183)$ & $3089(3089)$ & $1906(1906)$ & +723 \\
\hline за п.п. 1, 2, 4, 6, 9-1 ч. 1 ст. 284 КПК; & $1180(1180)$ & $3086(3086)$ & $1906(1906)$ & +723 \\
\hline за п. 10, абзацом 14 ч. 1 ст. 284 КПК; & & $1(1)$ & $1(1)$ & +1 \\
\hline $\begin{array}{l}\text { Кримінальні правопорушення, у яких на кінець звітного } \\
\text { періоду рішення не прийнято (про закінчення або зупинення) }\end{array}$ & $718(717)$ & $1282(1280)$ & $564(563)$ & -154 \\
\hline $\begin{array}{l}\text { Розділ } 9 \text { та розділ } 10 . \\
\text { Відомості про кримінальні правопорушення минулих років* } \\
\text { ^аналіз проведено без урахування окремо ст.164 КК, оскільки } \\
\text { цей показник окремо не обліковується } \\
\text { Кримінальні правопорушення проти виборчих, трудових } \\
\text { та інших особистих прав і свобод людини і громадянина, } \\
\text { у тому числі: }\end{array}$ & $6551^{*}$ & $5463^{*}$ & - & - \\
\hline проступки & & 1588 & & \\
\hline злочини & & 3875 & & \\
\hline
\end{tabular}


Таблиця 2

Загальні відомості про осіб, які вчинили кримінальні правопорушення по ст. 164 КК

Показник по ст. 164 КК України. Підготовлено на підставі аналізу:

- розділу 1 ( таб. 1.1), розділу 2 (таб. 2.1.), розділу 3 (таб.3.1.)

звітів за січень-червень 2020 року;

- розділу 1 (таб. 1.1), розділ 2 (таб. 1.1), розділ 3 (таб. 3.1.)

звіту за січень-грудень 2020 року [14].
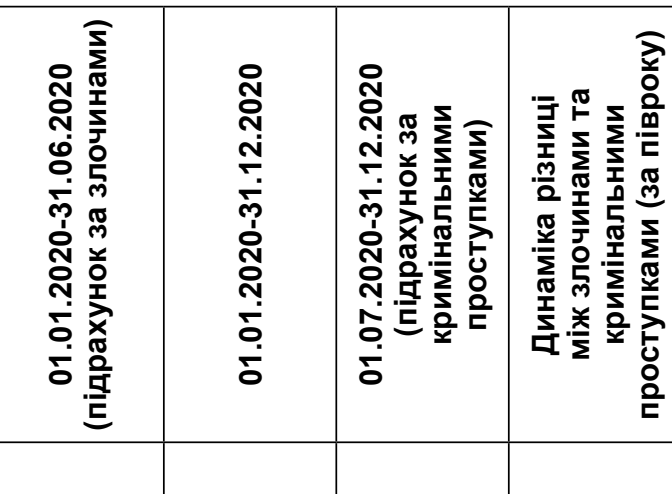

Розділ 1. Віковий, освітній склад та громадянство осіб,

які вчинили кримінальні правопорушення:

кількість осіб, яких повідомлено про підозру

кількість осіб, стосовно яких здійснено спеціальне досудове

розслідування

кількість осіб, стосовно яких кримінальні провадження закрито

за реабілітуючих підстав

виявлено осіб, які вчинили кримінальні правопорушення

за віком на час вчинення кримінального правопорушення

18-28;

29-39;

40-54;

$55-59$

60 та старші

в тому числі жінки

за освітою на час вчинення кримінального правопорушення:

повна вища і базова вища

професійно технічна

повна загальна середня та базова загальна середня

початкова загальна та без освіти

Громадянство на час вчинення кримінального правопорушення, в тому числі громадяни України

Розділ 2. Відомості про зайнятість осіб, які вчинили кримінальні правопорушення, в тому числі

працездатні, які не працюють і не навчаються

безробітні

Розділ 3. Відомості про осіб, які вчинили кримінальні правопорушення в групі, в стані сп'яніння, та повторно.

у складі групи

у стані сп'яніння

особами, які раніше вчиняли злочини, в тому числі судимість

не знята і не погашена

базовою вищою освітою менша (25 осіб), що свідчить про те, що особи з вищим рівнем освіти більш спроможні сплачувати аліменти, оскільки можуть знайти більш якісну роботу.

Фактично всі особи-правопорушники є громадянами України. На жаль, велика кількість осіб, які вчинили ці правопорушення, працездатні, але не працюють і не навчаються (381 особа). По цьому показнику маємо збільшення порівняно з попереднім періодом на 86 осіб. 20 осіб $€$ зареєстрованими безробітними. На підставі цих даних можна зробити висновок, що працез- датні особи не шукають виходу із ситуації, не стають на облік у центр зайнятості.

Ще одним елементом криміналістичної характеристики $є$ дані про особу потерпілого, можемо стверджувати, що це переважно жінки.

Наступним елементом криміналістичної характеристики $€$ дані про спосіб вчинення кримінального проступку. На підставі аналізу ст. 164 КК можна вважати, що є два самостійні способи його вчинення: перший, коли йдеться про ухилення від сплати аліментів за рішенням суду, та другий спосіб, коли підставою виплати 
коштів $є$ укладений договір про сплату аліментів на утримання дітей між платником та тією особою, яка утримує дітей.

Термін «ухилення» в кримінальному аспекті аналізується досить докладно в окремому дослідженні [15, с. 89], тому не потребує додаткового уточнення.

Під час аналізу такого елементу криміналістичної характеристики, як слідова картина проступку, що нами досліджується, маємо вказати на специфріку, зумовлену тим, що в більшості випадків слідами будуть документи, які свідчать про приховування доходу, зміну місця проживання чи місця роботи без повідомлення державного або приватного виконавця, документи, які свідчать про невиконання договору. Цій категорії справ фрактично не характерні криміналістичні сліди (ніг, рук, транспортних засобів та інші).

Методика розслідування передбачає формулювання переліку обставин, які потрібно встановити по даній категорії справ на підставі аналізу ст. 91 КПК та складу ст. 164 КК:

1) чи мало місце ухилення від сплати коштів (за який саме період, де це відбулося);

2) розмір грошових коштів, які потрібно було сплатити;

3) за який саме спосіб вчинення діяння;

4) хто має сплатити кошти;

5) якими саме доказами підтверджується винуватість особи.

Щоб повною мірою розкрити ці аспекти, потрібно звернутися до кримінально-правової характеристики досліджуваного кримінального проступку. Маємо зазначити наступне, ухилення від сплати аліментів на утримання дітей різновид «майнового» кримінального правопорушення, що вчиняється проти сім'ї та неповнолітніх.

Потерпілим від злісного ухилення від сплати встановлених рішенням суду коштів на утримання дітей (ст. 164 КК) у будь-якому випадку можуть бути особи, котрі не досягли встановленого національним законодавством віку, з якого настає повноліття (18-ти років), що є рідними дітьми винного, а так само й усиновленими чи удочереними особами. Крім того, потерпілим від цього кримінального правопорушення може бути й така категорія членів родини, як працездатні діти (рідні чи усиновлені) у віці від 18-ти до 23-х років, які продовжують навчання, а також повнолітні непрацездатні діти, які потребують матеріальної допомоги. У такому кримінальному правопорушенні, як злісне ухилення бать- ків від утримання неповнолітніх або непрацездатних дітей, що перебувають на їх утриманні (ст. 164 КК), потерпілими можуть бути не лише неповнолітні, але й малолітні особи, які $є$ рідними дітьми винного, а так само й усиновленими чи удочереними особами [16, с. 122].

3 об'єктивної сторони кримінальне правопорушення, передбачене ст. 164 КК України, виражається як у формі дії, так і в бездіяльності, які знаходять прояв:

а) у злісному ухиленні від сплати встановлених рішенням суду коштів на утримання дітей (аліментів);

б) у злісному ухиленні батьків від утримання неповнолітніх або непрацездатних дітей, що перебувають на їх утриманні $[17$, с. 22].

Проведений аналіз літературних джерел, зокрема робота Д.П. Євтєєвої, дав можливість виокремити наступне: предметом кримінального правопорушення, передбаченого ст. 164 КК, є засоби утримання в таких фрормах: 1) засоби утримання, що надаються в позасудовому та позадоговірному порядку; 2) аліменти за рішенням суду або за договором; 3) додаткові витрати, призначені судом або передбачені договором щодо сплати аліментів [18, с. 61].

Злісне ухилення від сплати коштів на утримання дітей (ст. 164 КК) може бути вчинене як із прямим, так і з непрямим умислом [19, с. 309].

Суб'єкт - спеціальний. За злісне ухилення від сплати аліментів на утримання дітей за ст. 164 можуть нести відповідальність батьки й усиновителі. Суб'єктами вчинення цього кримінального правопорушення у другій фрормі (злісне ухилення від утримання неповнолітніх або непрацездатних дітей) можуть бути лише кровні батьки або усиновителі.

Повертаючись до методики розслідування, зазначимо, що в методиці розслідування досліджуваного кримінального проступку потрібно вказати особливості початкового етапу розслідування. Про деякі проблеми цього етапу писав А.В. Столітній [9, с. 176], але виникають вони тільки у випадку, коли підставою для внесення даних в Єдиний реєстр досудових розслідувань (далі - ЄРДР) є інфрормування державного виконавця. Але деякі аспекти цього дослідження застаріли, тому ч. 11 ст. 71 Закону України «Про виконавче провадження» 2016 року [20] не накладає обов'язку на виконавця звертатися до правоохоронних органів, бо він, «за наявності заборгованості зі сплати аліментів, сукупний розмір якої перевищує суму відповідних платежів за три місяці, роз'яс- 
нює стягувачу право на звернення до органів досудового розслідування із заявою (повідомленням) про вчинене кримінальне правопорушення боржником, що полягає в ухиленні від сплати аліментів». Але у разі наявності договору про сплату аліментів на утримання дітей підставою може буде заява самого потерпілого, минаючи рекомендації державного або приватного виконавця.

Можемо погодитись зі А.В. Столітнім, що рух заяви про вчинення кримінального правопорушення проходить у два етапи:

1) дослідче провадження (на нашу думку, зараз точніше було б казати - провадження «до дізнання») - початкова стадія кримінального процесу, зміст якої становить діяльність із прийняття, реєстрації, розгляду, перевірки заяв і повідомлень про ознаки кримінального правопорушення;

2) внесення даних в ЄРДР - початок розслідування [9, с. 179], за процедурою, що визначена в новій редакції Інструкції МВС [21] та в Порядку ведення єдиного обліку в органах (підрозділах) поліції заяв і повідомлень про кримінальні правопорушення та інші події [22].

Ускладнює початковий етап дізнання по цій категорії справ той факт, що згідно з ч. 1 ст. 477 КПК ухилення без обтяжуючих обставин (ч. 1 ст. 164 КК) належить до категорії справ приватного обвинувачення, тобто дізнавач може розпочати провадження тільки після отримання заяви потерпілого.

Початковий етап перевірочних дій дізнавача по цій категорії справ з липня 2020 року передбачає більше можливостей (до внесення даних в ЄРДР). Згідно з ч. 3 ст. 214 КПК України під час розслідування справ про кримінальні проступки, для з'ясування обставин про їх скоєння, до внесення даних в ЄРДР можна проводити наступні дії:

1) відібрати пояснення;

2) провести медичне освідування;

3) отримати висновок спеціаліста і зняти показання технічних приладів та технічних засобів, що мають функції фото- і кінозйомки, відеозапису, чи засобів фото- і кінозйомки, відеозапису;

4) вилучити знаряддя i засоби вчинення кримінального проступку, речі і документи, що $€$ безпосереднім предметом кримінального проступку, або які виявлені під час затримання особи, особистого огляду або огляду речей [2], особливості проведення цих дій детально описані в літератури [23, с. 18-31].
Таким чином, пояснення осіб, результати медичного освідування, висновок спеціаліста, показання технічних приладів і технічних засобів, що мають функцію фото- та кінозйомки, відеозапису, чи засобів фото- і кінозйомки, відеозапису, все це джерела доказів, згідно зі ст. 298-1 КПК [2].

Але з огляду на специфіку слідоутворення досліджуваного проступку не всі ці дозволені засоби збору фактів можуть бути застосовані як до внесення даних в ЄРДР, так и після внесення. Проведення медичного освідування не специфічне, оскільки не має кваліфікаційного значення, так як це правопорушення має триваючий характер. Затримання в порядку ст. 208 КПК за загальним правилом взагалі застосується тільки у разі вчинення злочину, за виключеннями, передбаченими ч. 1 ст. 298-2 КПК, з дотриманням умов, що особа відмовляється виконувати законну вимогу уповноваженої особи щодо припинення кримінального проступку або чинить опір; намагається залишити місце вчинення кримінального проступку; під час безпосереднього переслідування після вчинення кримінального проступку не виконує законних вимог уповноваженої службової особи; перебуває у стані алкогольного, наркотичного чи іншого сп'яніння та може завдати шкоди собі або оточуючим [2]. Ухилення від сплати аліментів не можливо припинити в одну мить та в нього не має конкретного місця скоєння, а $є$ тільки фракт несплати коштів.

Частіше дізнавач зосереджує увагу на отриманні пояснень та в деяких випадках, коли це можливо, - на отриманні висновків спеціалістів та знятті показань технічних приладів та технічних засобів, згідно з п. 3 ч. 3 ст. 214 КПК.

Як обґрунтовано підкреслює А.В. Столітній, про фракт злісності можуть свідчити «тривалість ухилення, продовження ухилення після попередження з боку судді чи державного виконавця про необхідність виконання свого обов'язку та можливість притягнення до кримінальної відповідальності, неодноразові звернення потерпілого чи інших осіб до винної особи із цього приводу, відмова від пошуку роботи (не реєстрація у центрі зайнятості» [9, с. 176].

Адвокат О. Кухаренко наголошує на необґрунтованості постанови про закриття кримінального провадження за відсутністю складу кримінального правопорушення, що в матеріалах провадження відсутні відомості про те, чи перебував боржник за весь період несплати аліментів у центрі зайнятості, чи пропонува- 
лося йому працевлаштування; відсутні відомості про його матеріальний стан; про перевірку джерел доходів його існування [7]. Дізнавач в ході дізнання повинен зосередити свої дії на з'ясування саме цих обставин у ході отримання пояснень, витребування документів, зняття показань з технічних приладів.

Подальший етап дізнання повинен бути зосереджений на повідомленні про підозру та доказуванні вини особи. В криміналістичному плані, на відміну від злочину, цей етап характеризується більш стислими строками, оскільки згідно з ч. 3 ст. 219 КПК максимальний строк 3 дня повідомлення про підозру складає один місяць (по досліджуваному проступку в силу його специфріки - з самого початку - моменту внесення даних в ЄРДР зрозуміло, хто саме є платником грошей). Але, системне тлумачення ст. 219 КПК дає змогу зазначити, що на відміну від злочину (див. ч. 2 ст. 219 КПК), по проступку прописано початок строку дізнання - 3 моменту внесення даних в ЄРДР, та не вказуються окремі загальні строки для дізнання з моменту внесення даних в ЄРДР до моменту повідомлення про підозру у вчиненні проступку. Якщо цей час не регламентовано, то дізнавач, зловживаючи, може затягувати терміни повідомлення про підозру на значний, не обмежений законодавством, час. Запобіжником в такому випадку може бути тільки - строк давності притягання до кримінальної відповідальності.

Ускладнює процес дізнання по цих справах і той фракт, що згідно з ч. 3 ст. 38 КПК дізнанням можуть займатися нарівні з підрозділом дізнання, інші уповноважені особи Національної поліції, які, на жаль, не в повному обсязі обізнані з сімейним та кримінально-процесуальним законодавством та не мають навичок володіння криміналістичною методикою, про що свідчить велика кількість справ, які були закриті.

Висновки. Таким чином, досліджуючи стан розслідування кримінальних проступків органами дізнання, можна підкреслити неефективність дізнання по даній категорії справ. Як наслідок цього недостатню караність, що вказує на те, що практичні працівники стикаються із значними труднощами доказування особливо на початковому етапі.

Недостатня караність породжує неефективність ст. 164 КК України, ситуацію, коли превентивні фрункції не виконуються.

Збільшення кількості закритих проваджень фактично свідчіть про неспроможність органів дізнання доказати вину особи у вчиненні дослі- джуваного нами проступку та повідомити про підозру. Тому потребують доопрацювання методичні рекомендації щодо розслідування кримінальних проступків за ст.164 КК України.

\section{Список використаної літератури:}

1. Кримінальний кодекс України: Закон України від 05.04.2001 № 2341-III. Дата оновлення: 30.12.2021 p. URL: http://zakon4.rada.gov.ua/laws/ show/2341-14 (дата звернення:16.01.2020).

2. Кримінально-процесуальний кодекс України: Закон України від 13 квітня 2012 року № 4652-VI. Дата оновлення 14.01.2021. URL: http://zakon4. rada.gov.ua/laws/show/4651-17 (дата звернення: 16.01.2021).

3. Конституція України. Закон від 28.06.1996 р. № 254к/96-ВР. Дата оновлення від 07.02.2019. URL: https://zakon.rada.gov.ua/laws/show/254\% D0\%BA/96-\%D0\%B2\%D1\%80\#n4378 (дата звернення: 16.01.2021).

4. Конвенція ООН про права дитини від 20 листопада 1989 р. Дата оновлення: 20.11.2014 (ратифікована Україною згідно з Постановою Верховної Ради України від 27 лютого 1991 р. № 789-XII). URL: https://zakon.rada.gov. ua/rada/show/995_021\#Text (дата звернення: 16.01.2021).

5. Сімейний кодекс України від 10 січня 2002 року № 2947-III. Дата оновлення: 01.01.2021. URL: https://zakon.rada.gov.ua/rada/show/2947-14\#Text (дата звернення: 16.01.2021).

6. Судова практика у справах про злісне ухилення від сплати аліментів на утримання дітей. Узагальнення опрацьовано Овчинниковим Є.І., Солотким C.A. URL: https://zakon.rada.gov.ua/ rada/show/n0002697-04\#Text (дата звернення: 16.01.2021).

7. Кухаренко О. Як скасувати постанову слідчого про закриття кримінального провадження за ч. 1 ст. 164 КК України? (ухилення від сплати аліментів на утримання дітей). 24.09.2019 року: URL: https://disputes.ua/ua/ blog/success/skasovano-postanovu-slidchogopro-zakrittya-kriminalnogo-provadzhennya-zachastinoyu-1-statti-164-kk-ukrajini-ukhilennyavid-splati-alimentiv-na-utrimannya-ditej/ (дата звернення: 16.01.2021).

8. Щотижневий аналіз судової практики з сімейного права. 19.08.2020. URL: https://www.hsa. org.ua/blog/shhotyzhnevyj-oglyad-sudovoyipraktyky-z-simejnogo-prava/ (дата звернення: 16.01.2021).

9. Столітній А.В. Особливості початку досудового розслідування за ухилення від сплати аліментів на підставі подань (повідомлень) державної виконавчої служби. Актуальні проблеми держави і права : зб. наук. пр. / редкол. : В.В. Завальнюк (голов. ред.) [та ін.] ; відп. за 
вип. М.В. Афранасьєва. Одеса : Юрид. л-ра, 2015. Вип. 75. С. 175-181.

10.Єдиний реєстр судових рішень. URL: https:// reyestr.court.gov.ua/Page/16. Заголовок 3 екрану. (дата звернення 16.01.2021).

11. Єдиний реєстр судових рішень URL:https:// reyestr.court.gov.ua/Page/12 Заголовок з екрану (дата звернення 16.01.2021).

12.Єдиний реєстрі боржників. URL: https://erb. minjust.gov.ua/\#/search-debtors Заголовок 3 екрану (дата звернення 16.01.2021).

13.Єдиний звіт про кримінальні правопорушення за грудень 2020 р. та за червень 2020 року. Сайт Oфріс Генерального прокурора. URL: https://www.gp.gov.ua/ua/stat_n_st?_m=fslib\&_

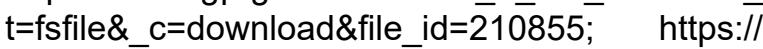
www.gp.gov.ua/ua/stat_n_st?_m=fslib\&_

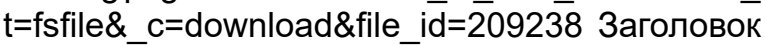
з екрану (дата звернення 16.01.2021).

14.Єдиний звіт про осіб, які скоїли кримінальні правопорушення за грудень 2020 р. та за червень 2020 року. Сайт Офіс Генерального прокуpopa. URL: https://www.gp.gov.ua/ua/stat_n_st? $m=f s l i b \&$ t $=f$ sfile\&_c $=$ download\&file_id $=\overline{2} 10 \overline{0} 85$; https://www.gp.gov.ua/ua/stat_n_st?_m=fslib\&_

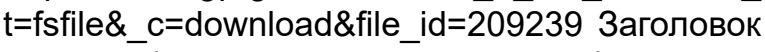
з екрану (дата звернення 16.01.2021).

15.Оксаніченко А.С. Поняття злісності за кримінальним правом України : дис... к-та юрид. наук : 12.00.08/Дніпропетровський державний університет внутрішніх справ. Дніпро. 2020. $221 \mathrm{c}$.

16.Семеногов І.В. Злочинне ухилення від утримання дітей або батьків (ст.ст. 164, 165 Кримінального кодексу України): досвід систематичного тлумачення ознак потерпілого. Вісник кримінологічної асоціації України. 2014. № 7. C. 215-223.

17.Бабенко А.М. Деякі проблеми визначення об'єктивних ознак злочинів ухилення від сплати алі- ментів на утримання дітей (ст. 164 КК України) та ухилення від сплати коштів на утримання непрацездатних батьків (ст. 165 КК України) / А.М. Бабенко. Південноукраїнський правничий часопис. 2015. № 2. С. 21-24.

18. Євтєєва Д.П. До питання про визначення предмета ухилення від сплати аліментів на утримання дітей (ст. 164 КК України). Вісник Луганського державного університету внутрішніх справ імені Е.О. Дідоренка. 2017. № 3(79). C. $58-67$.

19. Семеногов І.В. Теоретико-прикладні проблеми суб'єктивної сторони ухилення від сплати аліментів на утримання дітей. Вісник Кримінологічної асоціації України. 2015. № 1. C. 302-312.

20.Про виконавче провадження: Закон України від 2 червня 2016 року № 1404-VIII. Дата оновлення: 10.12.2020. URL: https://zakon.rada.gov. ua/laws/show/1404-19?find $=1 \&$ text=\%D0\%B0 \%D0\%BB\%D1\%96\%D0\%BC\%D0\%B5\%D0\%B D\%D1\%82\%D0\%B8\#w1_1 (Дата звернення : 21.01.2021).

21.Положення про Єдиний реєстр досудових розслідувань, затверджене Наказом Генерального прокурора від 30.06.2020 р. Дата оновлення: 31.08.2020 p. URL: http://zakon.rada.gov.ua/ laws/show/v0298905-20\#Text (дата звернення: 21.01.2021).

22.Про затвердження Порядку ведення єдиного обліку в органах (підрозділах) поліції заяв і повідомлень про кримінальні правопорушення та інші події. Наказ МВС України від 08.02.2019 № 100. Дата оновлення: 01.07.2020. URL: https:// zakon.rada.gov.ua/laws/show/z0223-19\#Text (дата звернення 21.01.2021).

23.Досудове розслідування кримінальних проступків [Текст] : метод. рек. / [С.С. Чернявський, М.С. Цуцкірідзе, Р.М. Дударець та ін.]. Київ : Нац. акад. внутр. справ, 2019. 160 с.

Pereverza O. Ya., Kulava M. K., Filipova N. A. Problematic issues of criminal law, criminological characteristics and investigation of criminal offenses for evading child support payments

Taking into account the changes that have taken place in the family, criminal, criminal procedural legislation and the growing number of children who need legal protection against non-payment of alimony by one of the parents for their maintenance, a comprehensive solution to the problem by means of various branches of law is relevant.

The study was carried out taking into account the innovations of Art. 12 of the Criminal Code of Ukraine and Chapter 25 of the Criminal Procedure Code of Ukraine regarding the concept of a criminal offense and procedural regulation of the features of pre-trial investigation of criminal offenses.

The criminal law, criminological and forensic characteristics of the commission of a criminal offense provided for by Article 164 of the Criminal Code of Ukraine have been carried out. The analysis was carried out on the basis of statistical data from the RRDR and the Unified Register of Court Decisions for the period from 01.07.2020 to 31.12.2020.

An attempt was made to determine other basic elements of the methodology for the investigation of criminal offenses of this category (the circumstances that need to be established for this category 
of cases, the features of the initial stage of the investigation, the implementation of the initial investigative actions, the features of the further stage of the investigation), that is, we are talking about the emergence of the formation of a new method of investigation the investigated criminal offense.

A list of circumstances that need to be established for this category of cases based on the analysis of Art. 91 of the Criminal Procedure Code and the composition of Art. 164 of the Criminal Code: whether there was an evasion of payment of funds (for what period, where it happened) the amount of money that had to be paid; for which particular method of committing the act; who should pay the funds; what kind of evidence confirms the guilt of the person.

It was stated that the initial stage of inquiry in this category of cases is complicated by the fact that, according to Part 1 of Article 477 of the Criminal Procedure Code, evasion without aggravating circumstances (Part 1 of Article 164 of the Criminal Code) belongs to the category of private prosecution cases, that is, the investigator can start proceedings only after receiving the victim's statement. The question about the tactical aspects of the moment of notification of suspicion in terms of the interpretation of the terms of inquiry under procedural legislation was raised.

It is concluded that practitioners have significant difficulties in the process of investigating criminal offenses of this category, in view of the fact that, according to procedural legislation, other authorized persons of the National Police can deal with inquest in this category of cases on a par with the inquest unit, requires further improvement of the procedural and methodological aspects of the problem under study.

Key words: criminal law characteristics, forensic characteristics, criminological characteristics, inquiries, evasion, payment of alimony, criminal offense, investigation technique. 